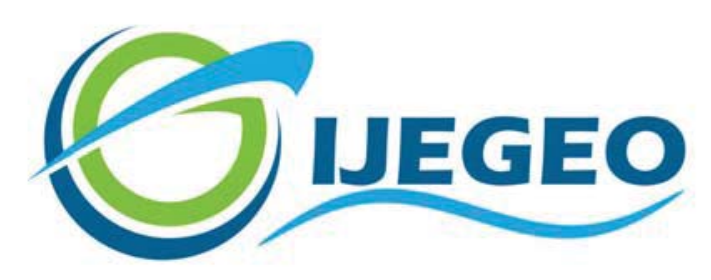

International Journal of Environment and Geoinformatics (IJEGEO) is an international, multidisciplinary, peer reviewed, open access journal.

\title{
Geospatial Evaluation of Building Facility in Oyo State, Southwestern Nigeria
}

\author{
Jimoh.R.A., Afonja.Y.O., Gbadebo.O.A., Sodiq .K.A., Otunubi .V.A., \\ Akintoye .S.O., Jimoh. A.A., Olanipekun.O.P., Obadaye. S., Chuma Vivian
}

\author{
Chief in Editor \\ Prof. Dr. Cem Gazioğlu \\ Co-Editors Prof. Dr. Dursun Zafer Şeker, Prof. Dr. Şinasi Kaya, \\ Prof. Dr. Ayşegül Tanık and Assist. Prof. Dr. Volkan Demir
}

Editorial Committee (June 2022)

Assoc. Prof. Dr. Abdullah Aksu (TR), Assoc. Prof. Dr. Uğur Algancı (TR), Assoc. Prof. Dr. Aslı Aslan (US), Prof. Dr. Levent Bat (TR), Prof. Dr. Paul Bates (UK), İrşad Bayırhan (TR), Prof. Dr. Bülent

Bayram (TR), Prof. Dr. Luis M. Botana (ES), Prof. Dr. Nuray Çağlar (TR), Prof. Dr. Sukanta Dash (IN), Dr. Soofia T. Elias (UK), Prof. Dr. A. Evren Erginal (TR), Assoc. Prof. Dr. Cüneyt Erenoğlu (TR), Dr. Dieter Fritsch (DE), Prof. Dr. Ç; Prof. Dr. Manik Kalubarme (IN), Dr. Hakan Kaya (TR), Assist. Prof. Dr. Serkan Kükrer (TR), Assoc. Prof. Dr. Maged Marghany (MY); Prof. Dr. Micheal Meadows (ZA), Prof. Dr. Nebiye Musaoğlu (TR), Prof. Dr. Masafumi Nakagawa (JP), Prof. Dr. Hasan Özdemir (TR), Prof. Dr. Chyssy Potsiou (GR), Prof. Dr. Erol Sarı (TR), Prof. Dr. Maria Paradiso (IT), Prof. Dr. Petros Patias (GR), Prof. Dr. Elif Sertel (TR), Prof. Dr. Nüket Sivri (TR), Prof. Dr. Füsun Balık Şanlı (TR), Dr. Duygu Ülker (TR), Prof. Dr. Seyfettin Tsaş (TR), Assoc. Prof. Dr. Ömer Suat Taşkın (TR), Assist. Prof. Dr. Tuba Ünsal (TR), Assist. Prof. Dr. Sibel Zeki (TR) 


\title{
Geospatial Evaluation of Building Facility in Oyo State, Southwestern Nigeria
}

\author{
Jimoh.R.A ${ }^{1}$ (D) Afonja.Y.O ${ }^{2}$ (iD , Gbadebo.O.A ${ }^{3}$ (D),Sodiq .K.A ${ }^{4}$ (D) ,Otunubi .V.A ${ }^{4}$ (D) , \\ Akintoye .S.O ${ }^{5}$ iD , Jimoh.A.A ${ }^{6}$ (D) Olanipekun.O.P. ${ }^{7}$ (D) , Obadaye. S. ${ }^{7}$ (D) Chuma Vivian $^{8}$
}

${ }^{1}$ Geomodeling and Geoexplore Consultants, Lagos State, Nigeria.

${ }^{2}$ Department of Surveying and Geoinformatics, Federal School of Surveying, Oyo State, Nigeria, ${ }^{3}$ Department of Civil Engineering, Federal University of Technology, Minna, Niger State, Nigeria, ${ }^{4}$ Department of Computer Engineering, Yaba College of Technology, Yaba, Lagos State, Nigeria , ${ }^{5}$ Department of Surveying and Geoinformatics, University of Lagos, Akoka, Lagos State, Nigeria ,'Department of Quantity Surveying, The Oke-Ogun Polytechnic, Saki, Oyo State, Nigeria., ${ }^{7}$ Department of Surveying and Geoinformatics, Rufus Giwa Polytechnic, Owo, Ondo State, Nigeria. ${ }^{8}$ Department of Hospitality and Tourism Management, Federal University Wukari, Taraba State, Nigeria

\begin{abstract}
Geospatial image acquisitions through the Unmanned Aerial Vehicle (UAV) techniques has been used geospatially to assess the Infrastructural building roof facilities of Emmanuel Alayande College of Education Campus, Oyo State, Nigeria. Unmanned Aerial Vehicle (UAV) is an aircraft without a human pilot on board, it is a veritable tool to solve numerous problems socially, and spatially which serves as an effective means of search, detection and identifying objects and the subjects of interest, as well as the precise determination of their coordinates. Drone deploy flight planning software were also used during this study. This paper focused on the building roof assessment of Emmanuel Alayande College of education Oyo. To achieve this aim, a UAV (Drone) was filed at a height to acquire the image data, which was processed using Argisoft Photoscan Professional image processing software and a orthomosaic, was acquire. The orthomosaic was analyzed with ArcGIS 10.3 and a map of building assessment of Campus was obtained. The findings shows geospatially how important is the geospatial technology for mapping roofs of infrastructure in this citadel of knowledge.
\end{abstract}

Keywords: Keywords: Mapping, Orthomosaic, ArcGIS 10.3, Unmanned Aerial Vehicle, Geospatial, image

\section{Introduction}

Geoinformatics as a science has witnessed several developments in the recent years in the types of instrument used in acquiring data, both spatial and nonspatial data. It has drastically transformed from analog form into digital form. Previously ground based method were mostly applicable, which ranges from chain surveying to the use of theodolites and later to the world of refined instrument such as Total Station, Scan Station, Smart Station, Differential Global Navigation System (DGNSS) and recently the Unmanned Aerial Systems (UAS), also called Unmanned Aerial Vehicle (UAV). An Unmanned Aerial Vehicle or Remotely Operated Aircrafts (ROAs) commonly known as drone is an aircraft without a human pilot on board. UAVs are a component of an unmanned aircraft system (UAS) which include a UAV, a ground based controller and a system of communications between the two. The flights of UAVs may operate with various degree of autonomy: either by a human operator or autonomously by onboard computers. Unmanned aerial vehicle offer less stressful environment, it is used for better decision making, it present safer environment (Anna, 2017).

Many fields of study including building facility assessment have adopted the Unmanned Aerial Systems (UAS) as a very useful tool. As Anna, 2017 puts it, in recent years research has developed following the use of digital images acquired through Unmanned Aerial Vehicles (UAVs), to monitor the technical condition of real estate and inventories of technical infrastructure (Bayirhan and Gazioğlu, 2020). The use of UAV can significantly improve the collection of geometric and structural data in such areas. Digital Surface Models (DSMs), Orthophotos and three-dimensional (3D) models derived from processed UAV images allow accurate mapping of joint geometries and their degree of uncertainty. The latest drone hardware and software developments allow their application in several fields of science, including the study of structure instability (Rau et al. 2011; Niethammer et al., 2012; Danzi et al., 2013; Salvini et al., 2014; Francioniet al., 2015; Giordan et al., 2015; Turner et al. 2015 as cited in Hellerann and Morgenthal 2013; Gazioğlu et al., 2017; Erenoğlu and Erenoğlu, 2018; İncekara and Şeker, 2021). Digital Surface Models (DSMs), orthophotos and threedimensional (3D) models derived from processed UAV images allow accurate mapping of buildings joint geometries and their degree of uncertainty. Zhang, (2008) confirms that recently, commercial remote sensing technologies have been introduced for pavement assessment (road assessment). UAV data can also be used both for calculation of yield (in terms of commercial value) and deterministic analysis of stability and the study of stress distribution within structures (in terms of safety) 
(Gönültaş et al., 2020). Expectedly, the continuous increase of the spatial resolution of space borne image. This paper aimed at evaluating the building facility of Emmanuel Alayande College of education campus, Oyo state, Nigeria using Geospatial Norms. Emmanuel Alayande College of Education is geographical located in Oyo Town, Oyo State embedded within a built-up area as seen in Figure 1 below. It lies between $7^{\circ} 52^{\prime} 24^{\prime}$ N, $7^{\circ}$ 53' 04 ' $\mathrm{N}$ and $3^{\circ} 53^{\prime} 50^{\prime \prime} \mathrm{E}, 3^{\circ} 54^{\prime} 38^{\prime \prime} \mathrm{E}$ with an approximate height of $277 \mathrm{~m}$ to $295 \mathrm{~m}$. It is a higher institution surrounded by the Erelu dam and comprises of a campus, which consist of academic and administrative units, as well as service centers.

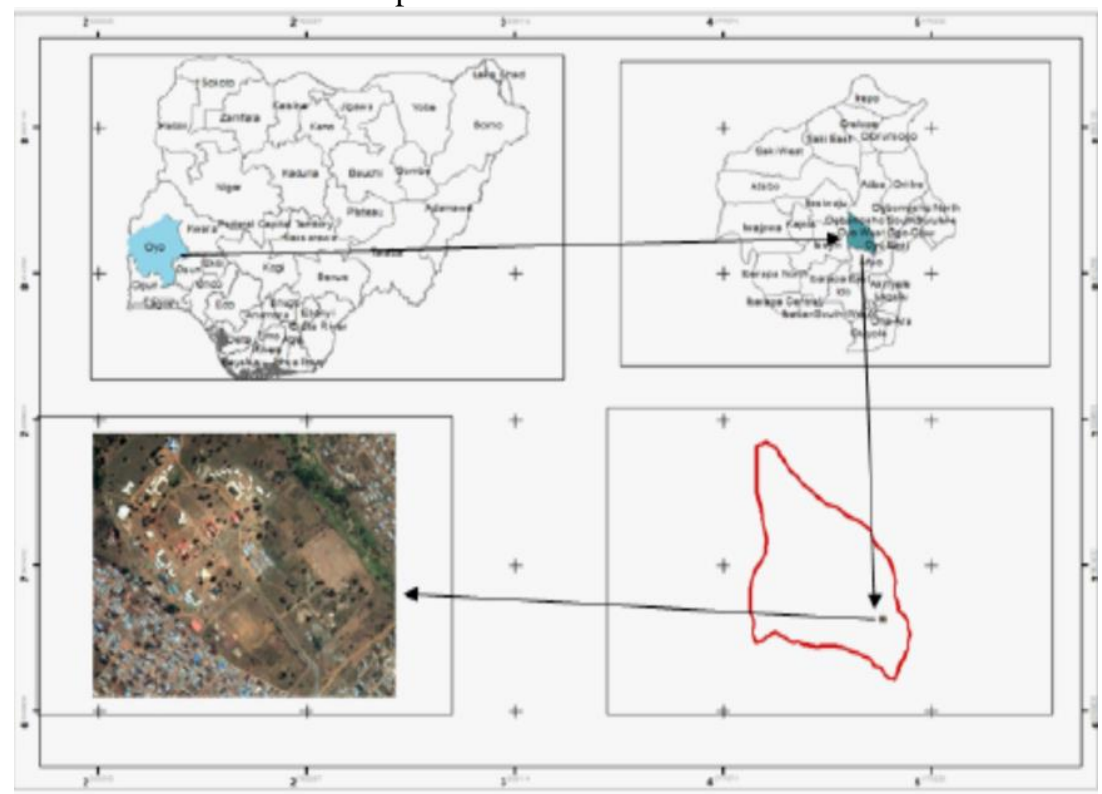

Fig.1: Map showing the study area

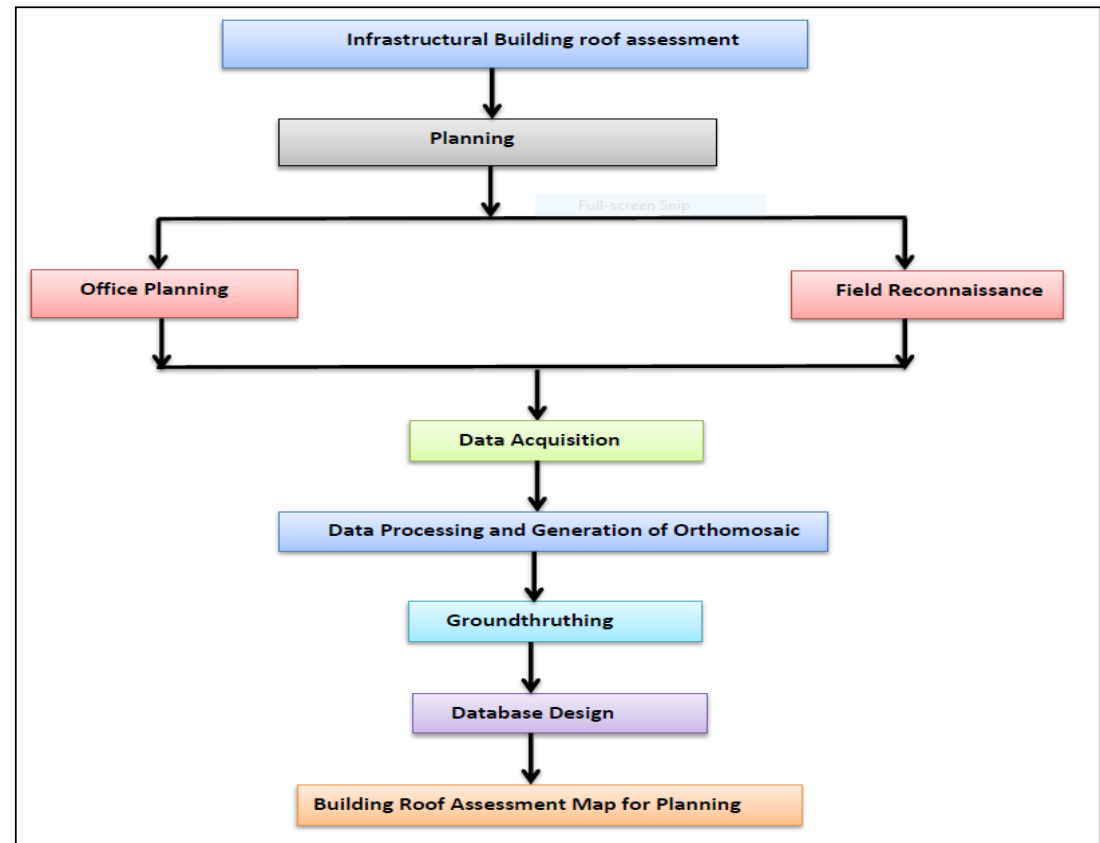

Fig.2: The Flow chart of process used in the assessment

\section{Methodology}

The Methodology deployed for this paper involved a reconnaissance survey, fixing of ground control points and check points (GCPs \& CPs), flight planning and execution, images processing to obtain orthomosaic, vectorization of Orthophotos map, ground truthing, database creation and query design, analysis and presentation of information in mosaic maps, charts and tables. A diagrammatic representation of the procedure deployed for this study is shown in Figure 2.
The flight campaign was conducted on 7th September 2019 when the weather was clear enough with a repeated flight due to the detection of a gross error in the first data on the 7 th October 2019, but this time the weather was a bit accommodating. The materials used for this study involved various datasets. These datasets includes Orthophotos acquired through an UAS flown at $80 \mathrm{~m}$ above ground level (AGL), at a side overlap of $65 \%$ and forward overlap of $75 \%$. Ground Control Points were also established in the study area for accuracy check. 
Establishment of Ground Control Points were done with nine (9) Ground Control Points (GCPs) regularly placed apart which were targeted by CHCx20 DGNSS, (GPS and GLONASS). The Ground Control Points (GCPs) horizontal and vertical accuracy was $15-20 \mathrm{~mm}$ as seen in
Figure 3. The GCPs on ground and the control check were assumed to be the same with the GCPs is shown in Figure 3 below, 3D models of the buildings and roads were acquired from the imagery as seen in figure 6 and the Ground control points values are shown in Table 1.

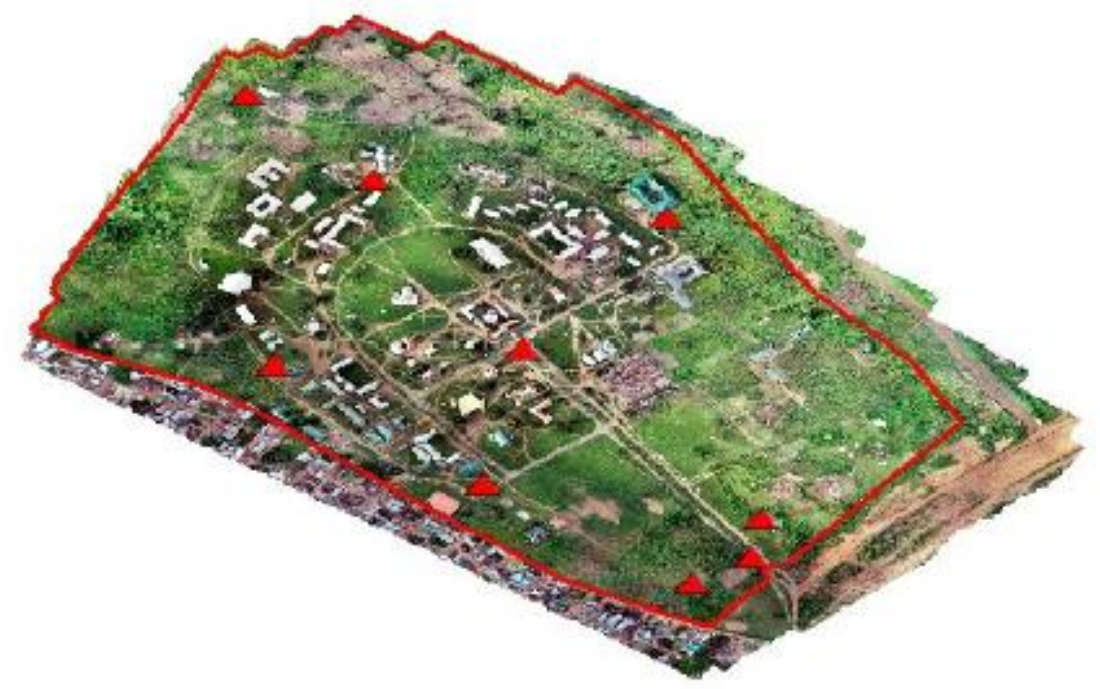

Fig.3: Ground Control Points used in the study area.

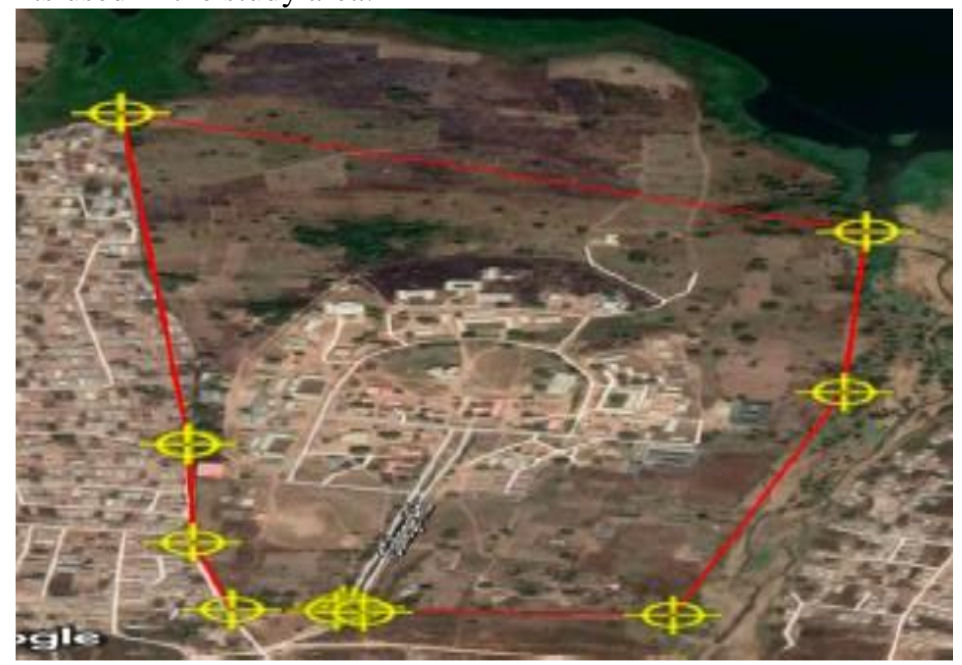

Fig 4: Field reconnaissance of the study area

However, field Reconnaissance survey were done as seen in Figure 4 by visiting and inspection of the site in order to have first-hand information about the study area and to determine various movement about the area in terms of equipment/instrument, personnel required, and ground control network.

\section{Image Data Acquisition}

The DJI Phantom 4 pro Drone as seen in Figure 5 was used in the image data acquisition. It is a lightweight quadcopter flying platform (with the following specifications: weight: $1388 \mathrm{~g}$, vertical GPS accuracy: $\pm 0.1 \mathrm{~m}$ (with vision positioning), $\pm 0.5 \mathrm{~m}$ (with GPS positioning) and horizontal GPS accuracy: $\pm 0.3 \mathrm{~m}$ (with vision positioning), $1.5 \mathrm{~m}$ (with GPS positioning). Max ascent speed; S-mode: $6 \mathrm{~m} / \mathrm{s}$, P-mode: $5 \mathrm{~m} / \mathrm{s}$. Max descent speed: S-mode 4m/s, P-mode: $3 \mathrm{~m} / \mathrm{s}$. Max speed; S-mode: 45mph, (72 kph), A-mode: $36 \mathrm{mph}$ (58 kph), P-mode: 31 mph (50 kph). Max tilt angle; S-mode; $42^{\circ}$, A-mode: $35^{\circ}$,P-mode: $25^{\circ}$. Max angular speed; S-mode: $250^{\circ} / \mathrm{s}$, Amode: $150 \%$ s. Max flight height: $6000 \mathrm{~m}$ Above Sea Level
(ASL). Max wind speed resistance: $10 \mathrm{~m} / \mathrm{s}$, max flight time: 30 minutes, operating temperature: $32^{\circ}$ to $140^{\circ} \mathrm{F}\left(0^{\circ}\right.$ to $40^{\circ} \mathrm{C}$ ), diagonal size: $350 \mathrm{~mm}$ (propellers excluded) robust carbon aluminum frame.

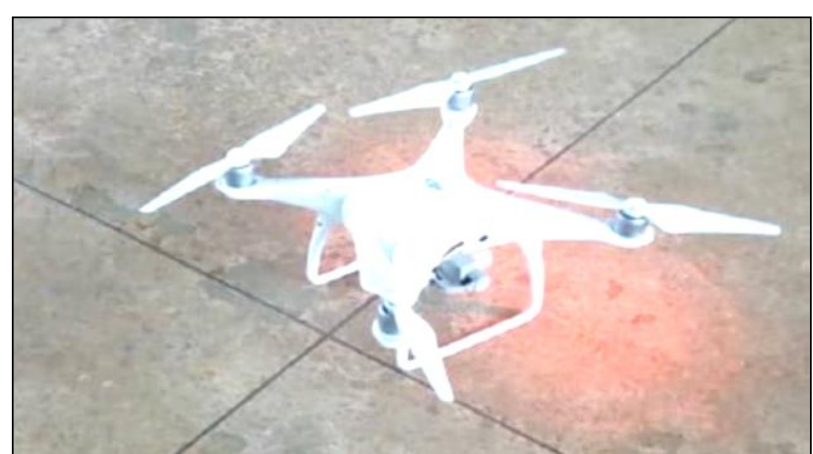

Fig.5: A DJI Phantom 4 Pro Drone used for image data acquisition.

It is stabilized by inertial measurement units (IMU); including gyroscopes, acceleration sensors, altimeter and 
compass. This unit is attached to a GPS (satellite positioning systems by GPS/GLONASS) unit with standard less than $2 \mathrm{~m}$ precision. Flight endurance with $5870 \mathrm{mAhLipo} 4 \mathrm{~S}$ batteries having voltage level of 15.2 $\mathrm{V}$, lasts up to 30 minutes. A compact mirror-less 1"CMOS sensor camera with $20 \mathrm{~m}$ effective pixel and FOV $84^{\circ}$ $8.8 \mathrm{~mm} / 24 \mathrm{~mm}$ (35mm format equivalent), $\mathrm{f} / 2.8-\mathrm{f} / 11$ auto focus at $1 \mathrm{~m}-\infty$ lens, was used for image acquisition, and ISO sensitivity, zoom and aperture were set at fixed values with exposure time between $8-1 / 800$ s. The system also has a vision component, which houses the obstacle sensory range and velocity range.

Table 1: Ground control points values.

\begin{tabular}{llll} 
CGP S/N & Latitude & Longitude & Elevation(m) \\
\hline 1 & 600552.3 & 870338.7 & 273.708 \\
2 & 600466.3 & 870284.5 & 277.399 \\
3 & 600171.8 & 870491.8 & 271.041 \\
4 & 599877.4 & 870740.0 & 261.765 \\
5 & 599838.8 & 871300.5 & 251.986 \\
6 & 600016.7 & 871120.0 & 257.195 \\
7 & 600430.8 & 871043.3 & 248.076 \\
8 & 600228.9 & 870772.2 & 264.762 \\
9 & 600567.0 & 870419.0 & 271.128 \\
\hline
\end{tabular}

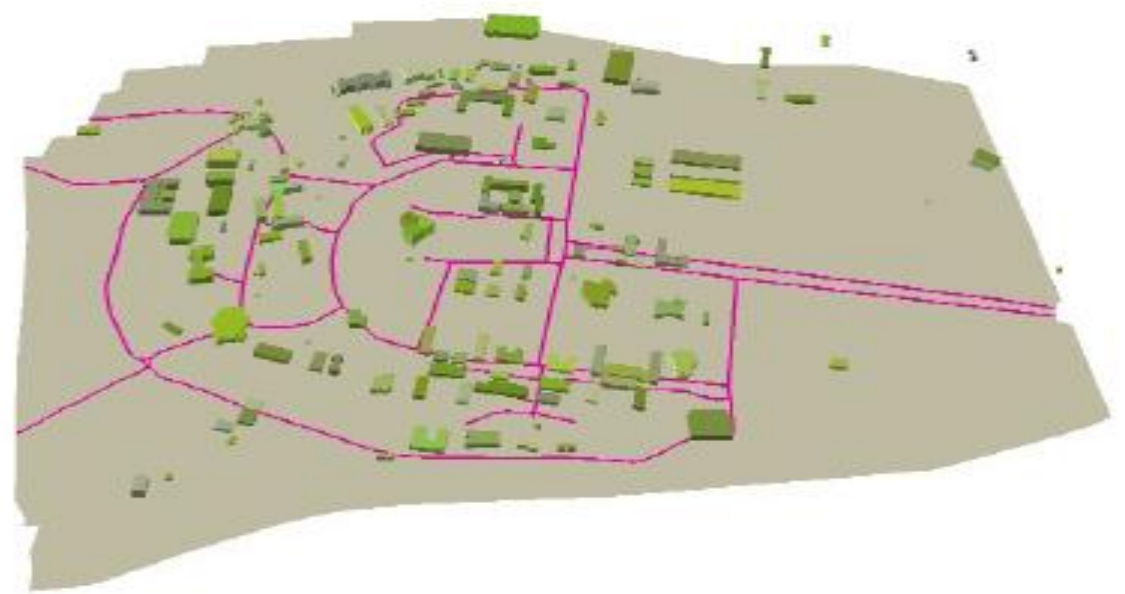

Fig.6: 3D model of buildings and road network.

\section{Image Data Processing}

A Total of 1,545 in number of UAV images were processed in the Agisoft Photoscan pro software processed to obtain a Orthomosaic image. The Orthophoto mosaic was then produced and exported. It is then vectorized for analysis on ArcGIS 10.3.The Agisoft Photoscan pro software uses Structural process from Motion algorithm (SfM) to reconstruct the actual surface from a large number of overlapping photos. The software locates matching features on each image and uses iterative bundle block adjustment to estimate image orientation, exterior orientation parameters and building model geometry. The GCPs were entered to aero triangulation, which enables precise calculation of the exterior orientation parameters and improves spatial georeferencing accuracy. The final step generates the

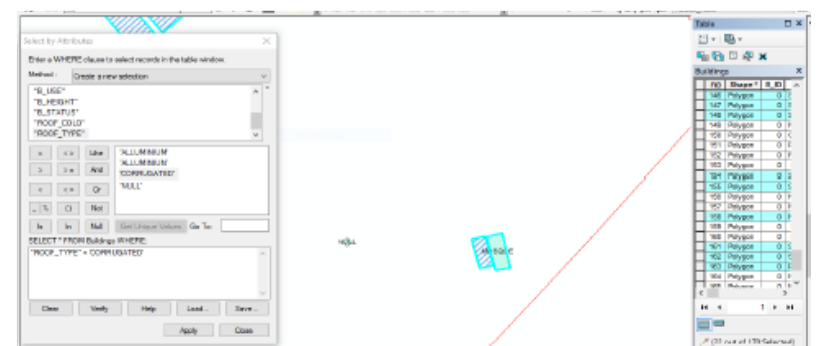

Fig 7: Query showing building roof that is corrugated Query: Return Buildings with Aluminum Roof (Type) base on their state of condition (Status) Syntax = "ROOF_TYPE" = 'Aluminum' AND "ROOF_STATU” = 'GOOD'
Digital Surface Model (DSM) by building the model texture and exporting a 2D model (mesh) or orthomosaic.

\section{Results and Discussion}

Data base query were done which involve SingleCriterion Query and Multiple-Criteria Query accordingly as seen in Fig 7 to Fig. 15 respectively. A model analysis was also performed as seen in Fig.16 to Fig.23 respectively. Spatial analyses were performed on the database created which is the vital important aspect of GIS. Virtually, all the important queries were done but only few were shown in this paper due to data security.

Query: Return All Buildings with Corrugated Roof Syntax=Roof Type $=$ Corrugated .

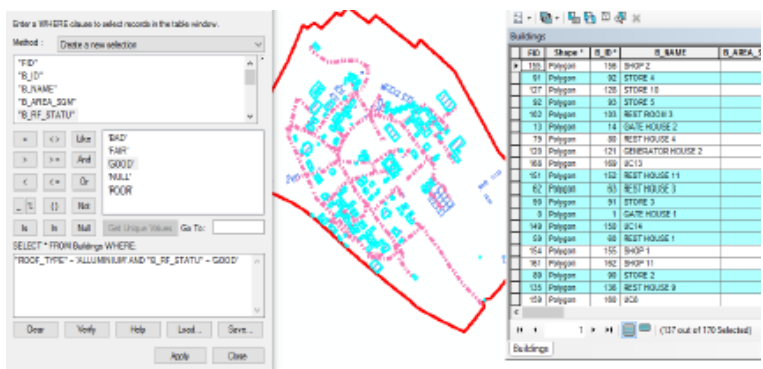

Fig 8: Query Showing building roof type and status Aluminum Roof in Good Condition

Syntax $=$ "ROOF_TYPE" = 'Aluminum' "BRF_STATU" = 'GOOD'
AND 


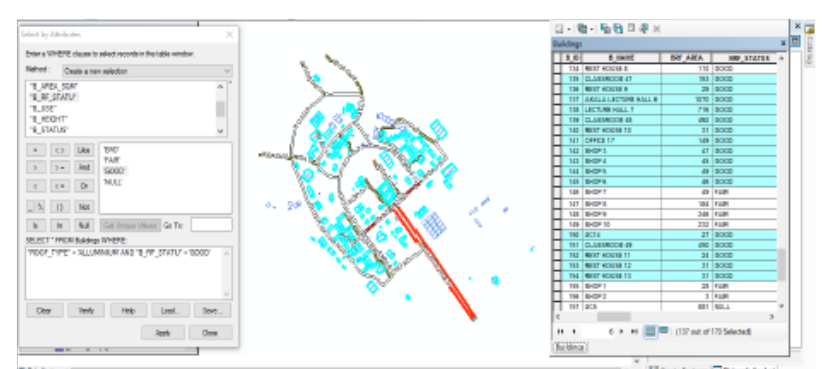

Fig 9: Query Showing Buildings with Aluminum Roof in Good Condition.

Aluminum Roof in Fair Condition

Syntax= "ROOF TYPE" = "Aluminum' AND "BRF_STATU" = 'FAIR'

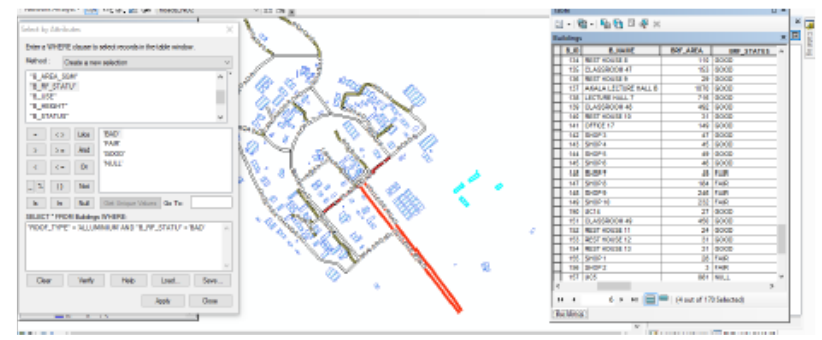

Fig 11: Query Showing Buildings with Aluminum Roof in Bad status.

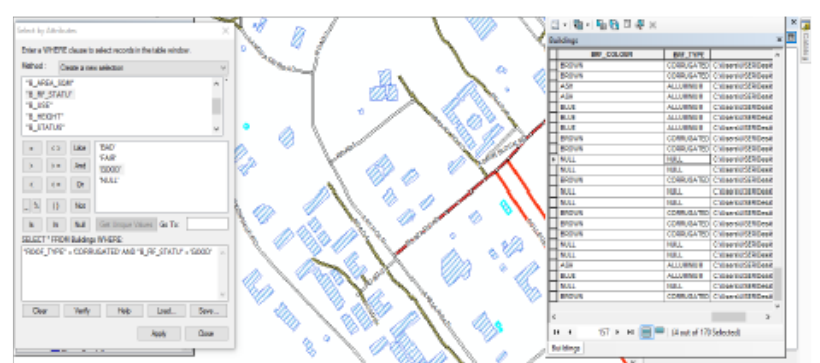

Fig 13: Query Showing Buildings with Corrugated Roofs in Good Condition

Corrugated Roof in Fair Condition

Syntax="ROOF TYPE"="CORRUGATED'AND"BRF STATUS" $={ }^{\circ}$ FAIR'

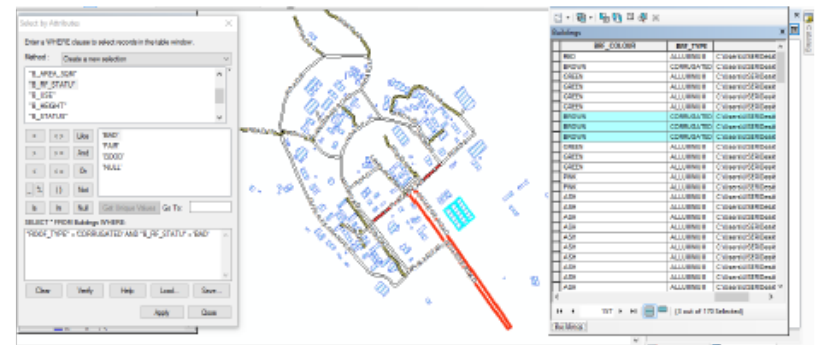

Fig 15: Query Showing Building with Corrugated Roofs in Bad Condition

All Buildings

Syntax=B_ID >= 1

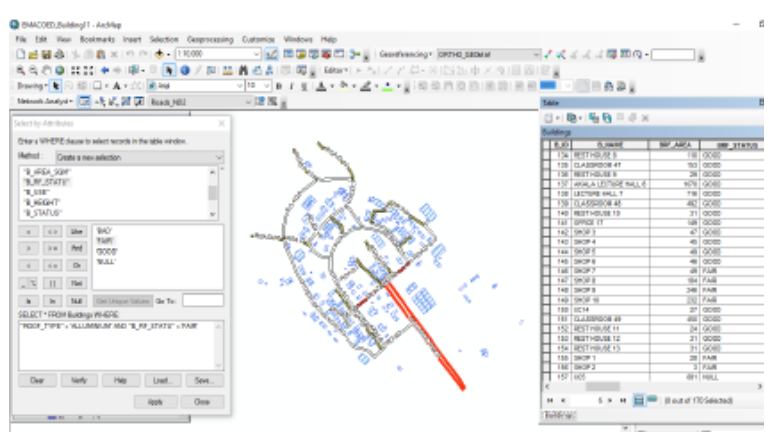

Fig 10: Query showing all buildings with Aluminum Roof of fair status

Aluminum Roof in Bad Condition

Syntax $=$ "ROOF TYPE" = 'Aluminum' AND "BRF_STATU"

$=$ 'BĀD'

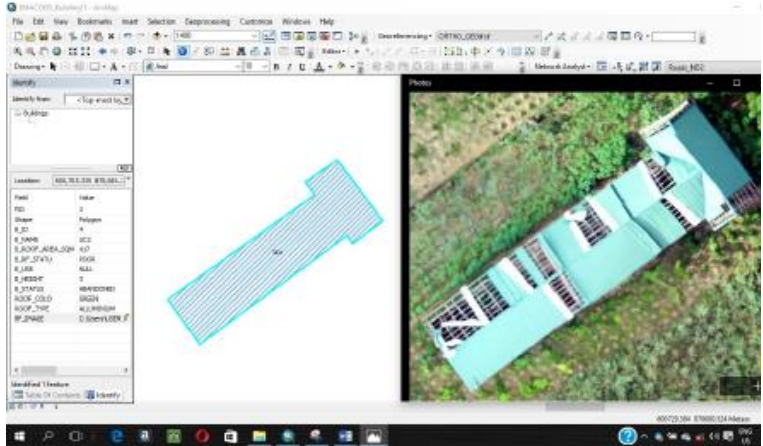

Fig 12: Query Showing hyperlink of Image of a Building with Aluminum Roof having Blue colour and of Bad Status Corrugated Roof in Good Condition Syntax="ROOF TYPE" = 'CORRUGATED' AND "BRF_STATUS" = 'GOOD'

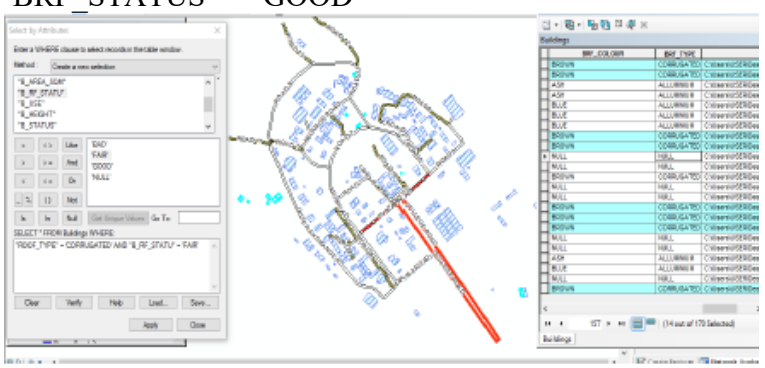

Fig 14: Query Showing Buildings with Corrugated Roofs in Fair Condition

Corrugated Roof in Bad Condition

Syntax="ROOF TYPE" = 'CORRUGATED' AND "BRF_STATUS" = 'BAD'
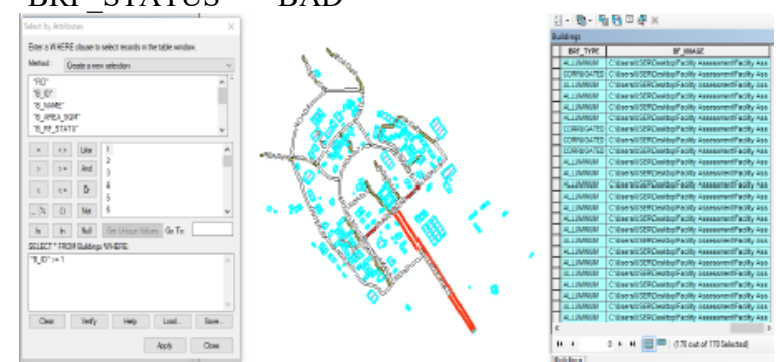

Fig: 16: Query showing all Buildings in the Study Area 


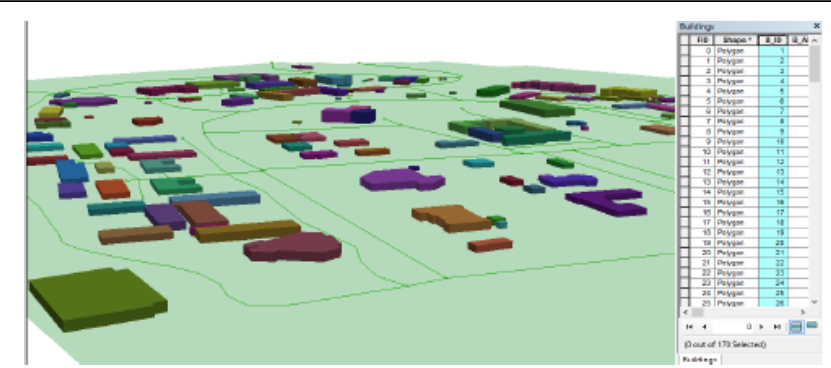

Fig 17: Query showing the 3D view of buildings in the study area Buildings with Aluminum Roof Syntax="ROOF_TYPE" = 'Aluminum'

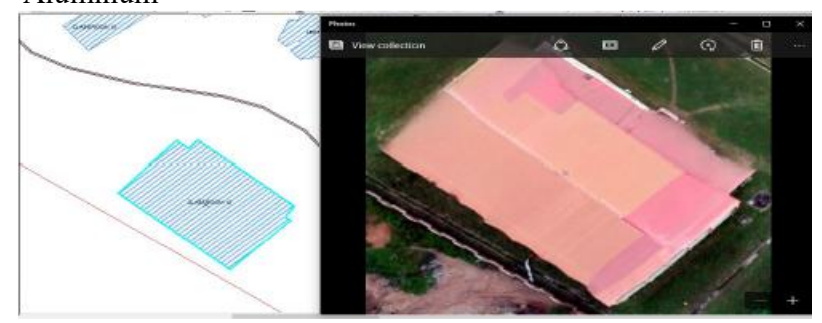

Fig. 19: Query Showing hyperlink of Image of a Building with Aluminum Roof

Buildings with Corrugated Roof Syntax="ROOF_TYPE" = 'Corrugated'

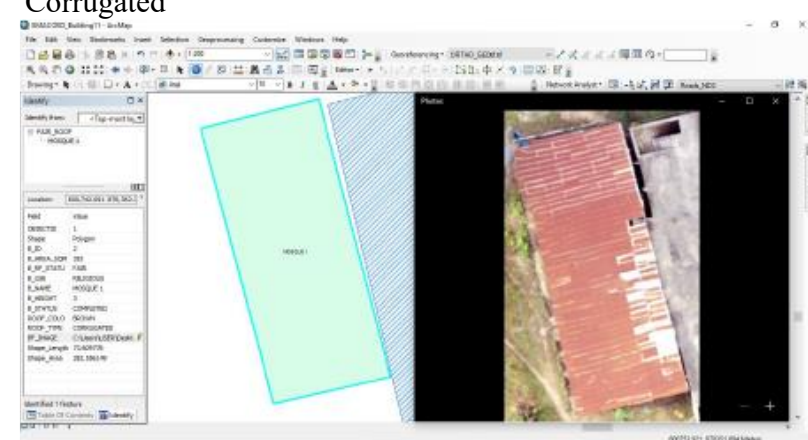

Fig.21: Query Showing hyperlink of Image of a Building with Corrugated Roof

Buildings without Roof

Syntax: "ROOF TYPE" = 'NULL'

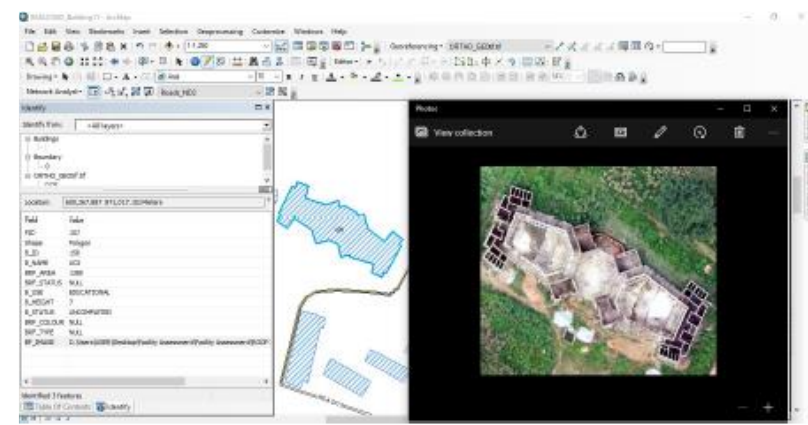

Fig.23: Query Showing hyperlink of Image of a Building without Roof

\section{Conclusion}

From the result obtained from this study, it is vividly deduced that, there are numerous ways of solving geospatial problems and supporting decision-making. The building roof assessment and mapping of Emmanuel Alayande College of Education was carried through remote sensing and GIS techniques involving UAV and

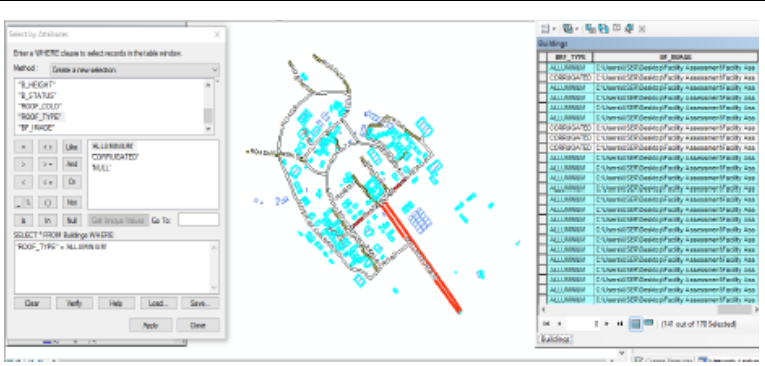

Fig. 18: Query showing all Buildings with Aluminum Roof

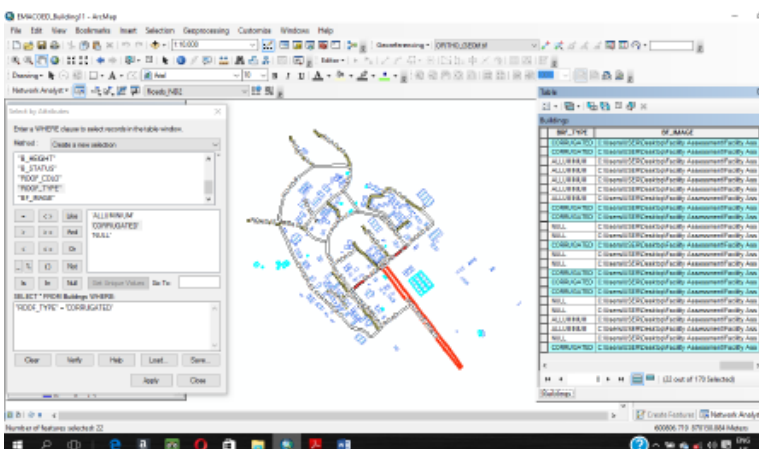

Fig.20: Query showing all Buildings with Corrugated Roof

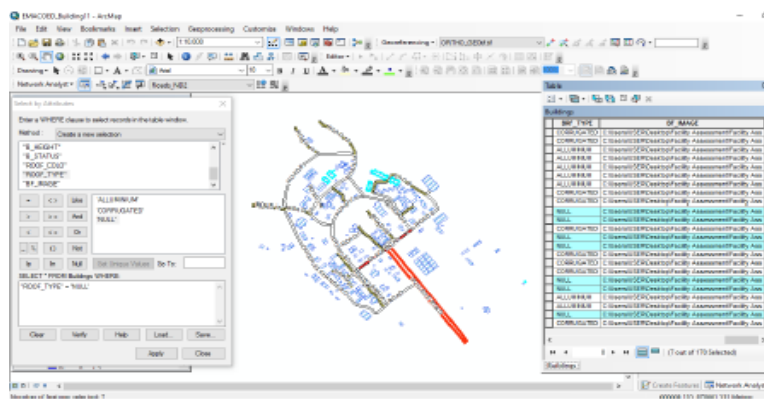

Fig.22: Query showing all the Buildings without Roof terrestrial data acquisition, processing, spatial analysis and map production. The project was executed by establishing ground control points, acquiring image data, processing image data, georeferencing and vectorization, as well as producing the desirables. The orthomosaic was digitized to generate features of interest. More so, ground trothing, updating, linking of attribute data with geometric data, spatial analysis and map production were done. The 
database creation and management was done using ArcGIS 10.3.This study has shown that archived information and detection of infrastructural faults on the building can really paved a way geospatially in solving problem relating to building.

\section{References}

Banaszek, A., Banaszk, S. and Cellmer, A. (2017).Possibilities of use of UAVs for technical inspection of buildings and constructions, IOP conference series: Earth environmental Science 95 (2017) 032001, World multidisciplinary Earth Symposium (WMESS 2017), doi.10:1088/175513/5/95/3/032001.

Bayırhan, I., Gazioğlu, C. (2020). Use of Unmanned Aerial Vehicles (UAV) and Marine Environment Simulator in Oil Pollution Investigations, Baltic J. Modern Computing, 8(2), 327-336, DOI: 10.22364/bjmc.2020.8.2.08.

Brdjanovic, D., Meijer, S. C., Lopez-Vazquez, C. M., Hooijmans, C. M., van Loosdrecht, M. C. (Eds.). (2015). Applications of activated sludge models. Iwa Publishing.

Dell'Acqua, F., and Gamba, P.(2012). Remote sensing and earthquake damage assessment: experiences, limits, and perspectives, Proceedings of the IEEE, Issue 100, 2876-2890.

Erenoglu, R. C., Erenoglu, O. (2018). A case study on the comparison of terrestrial methods and unmanned aerial vehicle technique in landslide surveys: Sarıcaeli landslide, Çanakkale, NW Turkey, International Journal of Environment and Geoinformatics, 5(3), 325-336, doi.10.30897/ijegeo.468061

Gazioğlu, C., Varol, ÖE., Şeker, DZ., Çağlar, N. (2017). Determination of the Environmental Impacts of Marine Accidents Using UAV and RS Technologies, 19th MESAEP Symposium on Environmental and Health Inequity, Roma, ITALYA, 3-6 Dec 2017.

Germanese, D., Leone, G., Moroni, D., Pascal, M. and Tampucci, N. (2018). Long-term monitoring of crack patterns in historic structures using UAVs and planner markers: A preliminary study, Journal of Imagin, 4, 99, doi:10.3390/jimaging4080099.

Gönültaş, F. , Atik, M. E., Duran, Z. (2020). Extraction of Roof Planes from Different Point Clouds Using RANSAC Algorithm, International Journal of Environment and Geoinformatics, 7(2), 165-171, doi. 10.30897/ijegeo.715510

Hellerann, N., Morgenthal, G. (2013) Unmanned aerial vehicles (UAV) for the assessment of existing structures.

İncekara, A. H., Seker, D. Z. (2021). Rolling Shutter Effect on the Accuracy of Photogrammetric Product Produced by Low-Cost UAV. International Journal of Environment and Geoinformatics, 8(4), 549-553, doi.10.30897/ ijegeo.948676.

Kerle, N., Frnand, G., Gerke, M. (2014). Urban structural damage assessment with oblique UAV imagery, object-based image analysis and semantics reasoning, conference paper.
Kufoniyi, O. (1998), Database design and creation on principles and application of GIS, Lagos, Panaf press, 46.

Murtiyoso, A., Grussenmeyer, P. (2017). Documentation of heritage building using closerange UAV images: dense matching issues, comparison and case studies, The photogrammetry record 32(159), 206-229 doi.10.1111/phor.12197.

Murtiyoso, A., Grussenmeyer, P., Koehl, M., Freville, T. (2016). Acquisition and processing experiences of close range UAV images for the $3 \mathrm{D}$ modeling of heritage buildings.

Murtiyoso, A., Remondino, F., Rupnik, E., Nex, F., Grussenmeyer, P., (2014). Oblique aerial photography tool for building inspection and damage assessment. International Archives of Photogrammetry, Remote Sensing and Spatial Information Sciences, 40, (1), 309-313.

Rupnik, E., Nex, F., Romendino, F. (2014). Oblique multi-camera systems-orientation and dense matching issues, The international Achieves of Photogrammetry, Remote Sensing and Spatial Information Sciences, 40 (3/W1), 107114.

Salvani, R., Mastrorocco, G., Seddaiu, M., Rossi, D., Vaneschi, C. (2017). The use of unmanned aerial vehicle for fracture mapping within a marble quarry (Carrara, Italy): Photogrammetry and discrete fracture network modeling, Geomatics, Natural Hazard and Risk, $\quad 8(1), \quad 34-52, \quad$ doi.10. 1080/19475705.2016.1199053.

Zhang, C. (2008). An UAV-based photogrammetric mapping system for road condition assessment, The International Archives of the Photogrammetry, Remote sensing and Spatial Information Sciences, Vol. XXXVII, part B5, pp.103-109. 